\title{
Limits of Brazilian public accounting and control systems to address the systemic corruption problem: lessons from the Swedish and Italian cases
}

\author{
Leice Maria Garcia 1 \\ Armindo dos Santos de Sousa Teodósio ${ }^{2}$ \\ 1 Governo Federal do Brasil / Controladoria-Geral da União, Rio de Janeiro / RJ - Brazil \\ 2 Pontifícia Universidade Católica de Minas Gerais, Belo Horizonte - MG - Brazil
}

\begin{abstract}
This article seeks to understand the reasons for the persistence of corruption in the Brazilian federal government, despite strong public accounting and financial control systems in the country. More than two-thirds of the states in the world, including Brazil, face the challenge of plundering public finances by political, economic, and bureaucratic elites. In this context, the exclusive use of the dominant approach of economic theories for the structuring of public control systems is limited. It is more appropriate to consider corruption as a problem of collective action. Hence, the theoretical reference chosen includes Bourdieu's theory of practice and Tocqueville's and Ostrom's collective action theories, as they have been understood respectively by Mungiu-Pippidi and Rothstein. The methodological strategy adopted is an exploratory analysis of the cases of contemporary day Brazil, based on the lessons learned from nineteenth-century Sweden, and Italy in the 1990s. The results indicated that overcoming systemic corruption requires more than control systems. It demands, at least, a trigger to disrupt the perverse social imbalance, institutional capacity to offer normative effectiveness and a cohesive and active civil society.
\end{abstract}

Keywords: corruption; public accounting; financial control; collective action; enforcement capacity.

\section{Análise de limites dos sistemas de contabilidade e controle para 0 enfretamento do problema da corrupção sistêmica no Brasil: lições dos casos da Suécia e da Itália.}

O artigo busca entender as razões para a persistência da corrupção no governo federal brasileiro, apesar de este nível de governo já contar com robustos sistemas de contabilidade pública e de controle financeiro. Mais de dois terços dos estados do mundo, incluindo o Brasil, enfrentam elevado nível de desvio de dinheiros públicos por parte de elites políticas, econômicas e burocráticas. Neste tipo de contexto, o uso exclusivo da abordagem dominante das teorias econômicas para a estruturação dos sistemas de controle público é muito limitado. O artigo defende que é mais adequado buscar soluções derivadas de abordagem das teorias de ação coletiva. Para isso utiliza a teoria da prática de Bourdieu e as teorias de ação coletiva, de Tocqueville e Ostrom, conforme acolhidas respectivamente por Mungiu-Pippidi e Rothstein. A estratégia metodológica é de análise exploratória do Brasil atual, à luz das lições da Suécia do século XIX e da Itália da década de 90. Os resultados indicam que a superação da corrupção sistêmica requer mais do que a constituição de sistemas de contabilidade e de controle fortes. Exige, no mínimo, um gatilho que desestabilize o equilíbrio social perverso vigente, capacidade institucional para conferir eficácia normativa, além de uma sociedade civil coesa e ativa.

Palavras-chave: corrupção; contabilidade pública; controle financeiro; ação coletiva; eficácia normativa.

\section{Análisis de los límites de los sistemas de contabilidad y control para enfrentar el problema de la corrupción sistémica en Brasil: lecciones de los casos de Suecia e Italia}

El artículo se propone a comprender las razones de la persistencia de la corrupción en el gobierno federal brasileño, aunque este ya cuente con comprensivos sistemas de contabilidad pública y control financiero. Más de dos tercios de los estados del mundo, incluso Brasil, enfrentan un alto nivel de desvío de dinero público por parte de las élites políticas, económicas y burocráticas. En este tipo de contexto, es muy limitado el uso exclusivo del abordaje dominante de las teorías económicas para la estructuración de los sistemas de control público. El artículo argumenta 
ser más apropiado buscar soluciones derivadas del enfoque de las teorías de acción colectiva. Él utiliza la teoría de la práctica de Bourdieu y las teorías de la acción colectiva de Tocqueville y Ostrom, conforme adoptadas por Mungiu-Pippidi y Rothstein, respectivamente. La estrategia metodológica es un análisis exploratorio del caso brasileño, a la luz de las lecciones de Suecia en el siglo XIX, e Italia en la década de 1990. Los resultados indican que superar la corrupción sistémica puede requerir más que establecer sistemas de contabilidad y de control fuerte. Es necesario, por lo mínimo, un gatillo que desestabilice el equilibrio social perverso existente, cierta capacidad institucional para conferir efectividad normativa y una sociedad civil activa y cohesiva.

Palabras clave: corrupción; contabilidad pública; control financiero; acción colectiva; efectividad normativa.

\section{INTRODUCTION}

The issue of corruption currently plays a central role in global debates. Even though it affects all countries, corruption is more significant in the so-called emerging democracies. Instead of prospering towards structures of good governance, the majority of them still cling to laws and practices that favor a monopolization of power. Under the rule of particularistic logic, the state is treated as an asset, and corruption is revealed as a systemic problem (Mungiu-Pippidi, 2013a, 2015).

Resorting to World Bank data (CoC 2012), Mungiu-Pippidi (2013a, 2015) built a governance ranking of 191 countries, showing that positive democracy, which promotes the common good with proper corruption control, prevailed in only 35 countries. In the rest, the winners of the political game consider the state a personal resource benefiting themselves or their peers, using typical strategies of patronage, nepotism, and exchange of favors.

Brazil is one such nation plagued by high levels of corruption. It affects the economic, social, and judicial relations, undermining the trust and social well-being of the population. Despite the State's efforts since the mid-1980s to promote institutional reforms, to align itself with the internationally prescribed strategies that aim at regulating, devising control structures, and strengthening judicial power, there is no perceived relevant progress. While reforms have taken place in the structure of Brazilian federal accounting and public control systems in the 1980s and 1990s, corruption has remained an everyday practice.

Currently, public bodies of control have unveiled an unprecedented fashion of the spurious relations between private and political Brazilian elites, and the perception about corruption in Brazil has worsened. Corruption indexes are showing a dramatic increase in Brazilian corruption perception since the start of Operation Car Wash in 2014. According to the International Transparency Index, Brazil was in the $69^{\text {th }}$ position in 2014 , and the $105^{\text {th }}$ in 2018 , falling 35 positions.

In order to understand why robust institutional control systems were not enough for Brazil to overcoming systemic corruption, this article studies the Brazilian case, in the light of the experiences from Sweden and Italy. Two main reasons justify the choice to tackle the Swedish case. First, Sweden has succeeded in overcoming corruption as a systemic problem in the nineteenth century. Second, the Swedish case has been studied by Rothstein for more than ten years, resulting in a consistent approach to systemic corruption. The choice to study the Italian case is based on the country's relative failure in fighting corruption during the 1990s. Italy went through Operation Clean Hands, which has similarities with Operation Car Wash. 
This study resorts to the theories of Bourdieu $(1983,1996,2014)$, Tocqueville (2005) and Ostrom (1990), and the perspectives of Rothstein and Mungiu-Pippidi to address the problem of corruption. The research adopted a qualitative approach and an exploratory analysis based on secondary data, using process tracing as a research tool. Process tracing allows scrutiny of processes by which initial conditions are transformed into specific results (Cunha \& Araújo, 2018).

The remaining sections of this article are organized as follows. Section 2 provides a brief theoretical introduction to corruption and an overview of the challenge of overcoming systemic corruption as a dilemma of collective action. Section 3 presents the cases of Sweden and Italy, based on information available in scientific papers, international statistical data, and research on multiple websites. Subsequently, in Section 4, the analytical schema provided by the cases of Sweden and Italy is used to analyze the Brazilian case. Finally, Section 5 brings final considerations.

\section{HOW CAN A COUNTRY TACKLE SYSTEMIC CORRUPTION?}

Corruption plays a central role in the current scientific, political, and economic debates worldwide. However, the concept remains a theoretical challenge (Filgueiras, 2007, 2009; Ferro, 2015; Rothstein \& Varraich, 2017). For Rothstein and Varraich (2017), corruption has been found in all times and every society, and the concept is grounded on the sense of opposition to the common good, the decadence of the state's purpose, and limitations to reach justice. However, there is still no consensual definition for the term "corruption."

The fields of law, sociology, political science, and economics have particular interpretations of corruption and provide theories to explain the problem. Within the field of law, there are three fundamental ideas around corruption throughout the evolution from the modern state to the rule of law model, a) the separation between the assets of the ruler and those of the state; b) the impersonality of the relations between the public realm and the citizen; and c) the common good as the state's purpose.

Sociology offers several theories for understanding corruption as a social practice. Pierre Bourdieu, based on his Theory of Practice, argues that the actions of agents can be understood in the reflexivity between structure and agency. In his analysis of public administration, the author supports Weber's view of the state as the community that successfully claimed a monopoly for the legitimate use of physical violence in a determined territory. For Bourdieu, this claim was only possible because jurists state "what is right," using universal ideas such as the notion of 'public interest.' The concept of public interest emerges as a symbolic capital also monopolized by the state. The author shows that the fundamental ideas brought historically by the jurists have a deep sense of symbolism, which leads people to submit to state authority (Bourdieu, 1996).

People's submission to the state, however, depends on the population recognizing that the state deserves the symbolic capital it claims to represent. The maintenance of this capital and access to resources it entails requires agents who represent the state to submit to the authority grounded on the same symbolism (or at least appear to submit). In practice, it means that the agents of the state must renounce their private - especially economic - interests. Therefore, Bourdieu (1996) argues that the habitus of the state's bureaucracy is to work nonstop to make the public agent's point of view coincide with the point of view that legitimizes the state's existence (Garcia, 2011). 
The challenge for the state is reflected in the gap between the norm and the administrative practices. The distance between norms and practices may be observed through administrative incapacity, delays, influence peddling, and private use of the public sphere. More than two-thirds of the world's countries still cannot put into practice the state's promise to promote the common good. In these countries, republicanism is still unstable, and policymaking and implementation may be biased, giving room to 'systemic corruption.'

The most dominant theoretical approach for the issue of alignment between the symbolic norm and official practices has been the new institutional economics, notably, the rent-seeking theory and the principal-agent theory (Krueger, 1974; Jensen \& Meckling, 1976). Based on these theories, RoseAckerman $(1978,2002)$ provided the most influential understanding of corruption, associating it to the abuse of public duties, to the misuse of public resources, and the illegitimate use of political influence by public and private agents. This understanding sheds light on the meaning of the abuse carried out by public and private agents against the public sphere when they act rationally for their own benefit, which harms the public interest. Since the 1990s, these ideas have supported states' reforms, based on holistic strategies.

Nevertheless, current studies indicate that the economic perspective has not provided a positive response to reforms made in many countries (Stefes, 2007; Rothstein, 2007; Mungiu-Pippidi, 2013a, 2013b; Persson, Rothstein, \& Teorell, 2013; Rothstein \& Varraich, 2017). Persson, Rothstein, and Teorell (2013) conducted a study on the reasons why the reforms implemented in Uganda and Kenya, since the late 1990s, failed to bring about the intended changes. In the study, the authors warn that the answer lies partly in the inadequacy of assumptions of the reforms, grounded on the principalagent problem.

The Principal-Agent Theory is the main basis for the creation of mechanisms of institutional control. The theory presupposes the existence of a principal interested in controlling the agent, for the common good. The "principal" can be, for example, the bureaucracy that produces the regulations (institutions), the members of parliament who vote and approve the regulations, the high-echelon public servants who authorize contracts between the public administration and the private sector. The principal may also be a citizen willing to understand the public workings with a view of being an efficient watchdog.

The central problem perceived is that the actions of these principals, in the researched countries, are guided by personal interests. In the absence of the 'incorruptible principal', the reforms proposed under the Agency Theory have failed. In one of Pierre Bourdieu's last works, in the 90s, he stressed the critical role of the principal, foreseeing that the absence of principals focused on the common good was a relevant limit for the effectiveness of public control systems (Bourdieu, 2014).

More recently, Teorell and Rothstein (2012) defended that, in the context of systemic corruption - where the presence of a principal is uncertain - the Agency Theory needs to be complemented with the collective action approach, and adopted Ostrom's Theory of Collective Action. One of the collective problems studied by Ostrom was the difficulty of cooperation of a group of fishermen who work in the same lake. As the profit of each of them is directly proportional to the number of fish caught, each fisherman has an incentive to lay as many nets as possible. The long term result from this lack of cooperation may be the decline in fish yield. Ostrom (1990) 
argues that the problem must be separated into three distinct problems: the problem of who will supply the solution, the problem of credible commitments, and the problem of monitoring. The author proved that, in this case, it is the group of fishermen that can present solutions for each of the three problems.

Rothstein and Teorell, based on the work by Ostrom, studied the Swedish case and advocated that agents with common purposes can act together to "replace the old order with a new one by the force of their own making” (Teorell \& Rothstein, 2012, p. 4). The authors considered systemic corruption as a problem of collective action, pointing out the need for a theory to explain how to overcome the problems of collective action and how 'new rules of the game' can become dominant practices. For them, even if people realize that everybody might lose with corruption-based choices, they will act in a corrupted way if they believe others will do the same.

Another relevant point of view for this kind of problem is brought by Mungiu-Pippidi, based on Alexis de Tocqueville's vision of collective action. Observing nineteenth-century American democracy, Tocqueville was convinced that "collective force" was fundamental for creating common good in a state (Tocqueville, 2005, pp. 160, 278, 279). The quality of collective action identified in American society appears in Tocqueville as a consequence of four factors: popular sovereignty, equality and law enforcement to all on equal terms, the associative spirit, and independent press.

In order to test the Tocqueville's ideas, Mungiu-Pippidi carried out quantitative research with World Values Survey data, between 1995 and 2008. The author found a positive correlation between the number of civil associations and political engagement and the number of civil associations, the existence of independent media, and control of corruption. Then, the author upholds that cooperation and the habit of association generate social capital, which in turn favors collective action (MungiuPippidi, 2013a, 2015). Since the collective force is efficient to broaden trust-based relations, the author defends that level of association is paramount for the development of new rules of the game in societies characterized by systemic corruption.

Three relevant ideas emerged as fundamental to discussing systemic corruption. First, public agents committed to the common good result from a process of social construction, in a reflexivity process between structure and agent, as taught by Bourdieu. Agents interested in the common good are not born ready, they are formed in the socio-historical reflexivity where they live. Second, in countries dominated by systemic corruption, the reform proposals cannot presuppose the existence of the principal to make up the principal-agent relationship. Third, the collective action approaches used respectively by Rothstein and Mungiu-Pippidi bring two different elements. For Rothstein, the solution is the cooperation between institutional agents. For Mungiu-Pippidi, the problem is the ability of society to work in associations and restrict the perverse behavior of the authorities.

The next section of the article analyzes the cases of Sweden and Italy to verify the relevance of the theoretical points and central elements in the results obtained by the countries. These elements will be used to analyze the limits of the public accounting and control systems to address the Brazilian corruption problem in Section 4. 


\section{THE CASES OF SWEDEN AND ITALY}

\subsection{The Swedish case}

Rothstein has shown that, in the nineteenth century, the Swedish State displayed the characteristics found in systematically corrupted societies. Personal contacts in the "king's entourage" opened doors, the elites had more access to public office, obedience and abidance to laws and norms were not the common, and public jobs were regarded as property. Rothstein also shows that Sweden's transition into the condition of a country with proper corruption control did not occur incrementally or by sectors, as shown in Box 1.

\section{BOX 1 INSTITUTIONAL CHANGES}

\begin{tabular}{|c|c|}
\hline PERIOD & NEW LAW OR NEW RULES \\
\hline $1842-1862$ & $\begin{array}{l}\text { Mandatory and free basic education for everyone is established together with the National Board of School } \\
\text { Inspectors. }\end{array}$ \\
\hline 1845 & The right for the government to confiscate newspapers is abolished (freedom of the press). \\
\hline 1845 & The formal aristocratic prerogative for higher positions is abolished. \\
\hline 1845 & Law about the right to equal inheritance between men and women. \\
\hline 1846 & The guild system is abolished. \\
\hline 1848 & Introduction of the joint-stock company law. \\
\hline 1864 & Freedom of trade is established. \\
\hline 1853 & New rules for university education establishing higher standards for degrees. \\
\hline 1858 & Freedom of religion is established. \\
\hline 1870 & Jews can become civil servants. \\
\hline 1866 & $\begin{array}{l}\text { Reform of the Parliament - the four states system is abolished, and a "modern" bicameral Parliament is } \\
\text { established. }\end{array}$ \\
\hline $1840-1862$ & $\begin{array}{l}\text { Many new public boards/agencies are established for carrying out large investments in communication } \\
\text { infrastructure. Technical skills and merits became important. }\end{array}$ \\
\hline $1855-1860$ & Major revision of the wage system in the civil service. \\
\hline 1860 & The right to leave the State Church. \\
\hline 1862 & New criminal code includes a new law on misconduct in office. \\
\hline 1862 & New laws greatly increasing decentralization in public administration. \\
\hline 1878 & Start of the abolishment of the "accord system" and introduction of a working pension system for civil servants. \\
\hline 1868 & $\begin{array}{l}\text { Start of abolishing direct payments for services to individual civil servants. The payments passed to be } \\
\text { made to the State. }\end{array}$ \\
\hline 1869 & Taxes become to be paid in money instead of in goods. \\
\hline
\end{tabular}

Source: Rothstein (2007). 
The transition was carried out in less than 30 years, starting in the mid-nineteenth century, but the reasons for the social transformation lie in the trauma and losses that the country had with the war with Russia in the years 1808-1809 (Teorell \& Rothstein, 2012). Citing the writer August Strindberg, the author states that in the novel The Red Room, published in 1879, a character is a public servant. The description reveals the stereotypes of laziness and inefficiency, but no longer corruption as a feature associated with the State.

The change has remained historically. The country always ranks well in governance and corruption control indexes. It ranks third in the 2018 TI Index, and the 2012 Governance Index, proposed by Mungiu-Pippidi (2015), it appears in the third position, close behind New Zealand and Denmark.

Teorell and Rothstein $(2012$, p. 8) studied this Swedish transition and presented a new theory to explain how new rules of the social game can become dominant practices. Based on Ostrom (1990), they suggest an endogenous theory of institutional change. The argument is that state agents may "become alert of the collection action problem they are facing, and the collective costs they bear for retaining their corrupt and dysfunctional equilibrium behavior, and thereby themselves work out solutions that enable them to break out of this equilibrium" For the authors, overcoming corruption does not automatically occur solely from the efficiency of institutional control mechanisms. If efficient institutional devices "will make a country start spinning on a new path that leads it out of systemic corruption," more countries would have succeeded in curbing systemic corruption (Rothstein, 2007, p. 4).

BOX 2

\section{SWEDISH PATH OF CHANGE}

\begin{tabular}{|c|c|}
\hline Transition Time: & About 25 years (1850 -1875). \\
\hline Scope of the Changes: & $\begin{array}{l}\text { Explosive Change (Big Bang), involving most public institutions and private-sector elites. It } \\
\text { was nothing incremental or sector-specific. }\end{array}$ \\
\hline The trigger: & $\begin{array}{l}\text { Sweden lost Finland to Russia in the war of 1809. A significant part of society, including } \\
\text { politicians and bureaucrats, saw the problem of collective action they faced (risk of the } \\
\text { disappearance of the Swedish state), as well as the collective cost to maintain the level of } \\
\text { systemic balance of corrupt and dysfunctional behavior. }\end{array}$ \\
\hline Institutional background: & Previous judicial reforms occurred in the seventeenth century. \\
\hline Collective force: & $\begin{array}{l}\text { An endogenous movement of Swedish society and political class developed a new political } \\
\text { ideology, more democratic, liberal, and equalitarian. This thought counteracted and overcame } \\
\text { the perspective of the conservative aristocracy. }\end{array}$ \\
\hline
\end{tabular}

Source: Elaborated by the authors, based on Rothstein (2007), Teorell and Rothstein (2012) and Guimarães (2016).

Besides the cooperation between institutional agents cited by Teorell and Rothstein (2012), history shows the presence of great collective force in Sweden through the years. Sweden has always 
experienced strong levels of cooperation among social groups. There were never periods of slavery or servitude in the country, nor periods in which the peasant class was marginalized from institutional decision-making (Guimarães, 2016). Mungiu-Pippidi (2013a, 2015) argues that this habit of living together generates social capital, which in turn favors the force necessary to constrain economic, political, and bureaucratic elites to change their practices.

Box 2 shows three elements that emerge from the Swedish case, and they are important to promote the changes that may lead a country out of systemic corruption. These elements are a trigger that can provoke the possibility of sustainable cooperation among institutional decision-makers, an adequate level of institutional capacity, and a strong collective force.

\subsection{The Italian case}

Italy's most recognized attempt to deal with corruption occurred in the 1990s with Operation Clean Hands. It came four years after the significant criminal procedural reform that began to provide, among others, the possibility of the instrument of cooperation agreement (Vasconcellos, 2015).

The Operation started in February 1992, with the arrest of Mario Chiesa, politician member of the Italian Socialist Party, charged with taking kickbacks. Around one month later, isolated and without the support of his old political partners, Chiesa proposed to turn state's evidence (Vannucci, 2009; Sberna \&Vannucci, 2013; Guimarães, 2016 Vannucci, 2016).

Chiesa's information unveiled the most important corruption schemes between the political and economic elite in the country. When the arrests started, offenders agreed to turn state's evidence as well, weakening the Italian political and economic system. The loss of legitimacy of the systems increased the power of judicial action and, at the same time, was fed by the results of the investigations (Moro, 2004; Sberna \&Vannucci, 2013; Vannucci, 2016).

In a short time, the investigation had progressed in different fronts: a) at first, it included the leadership of all parties; and b) private businesspeople of every level and managers of public companies. Schemes to purchase and sell votes were uncovered, forming a criminal network made up of politicians, business people, and members of the Italian Mafia. Thirty-one people involved in the investigations committed suicide by 1994 (Guimarães, 2016; Vannucci, 2016).

In March 1993, Italian legal structure changes started, as can be observed in Box 3. They gained strength after the election of Silvio Berlusconi in 1994. Although he was involved in the investigations, the billionaire Italian businessman, owner of communication companies and the soccer team A.C. Milan, was elected prime minister, taking advantage of the vacuum of political discredit. He remained in office for six years and then, in 2008, was re-elected for four more years.

In 2002, when the Operation was considered complete, or at least disfigured, the result showed 1,254 people condemned, 430 acquitted, and 422 benefited by limitation periods and the rest not being sued. It is also interesting to observe the Transparency International indexes (Index TI) for the period between 1995 and 2018. They can show the Operation did not manage to bring Italy to a suitable control of corruption. In 2018, Italy ranked 58 out of 180 countries. The result has placed the country among the Western European countries with the worst corruption control. In the case of the index proposed by Mungiu-Pippidi (2015), Italy scored 4.54 in 2012. According to this index, 
Italy is one of the 109 countries in the world, where the particularistic logic prevails in the relations involving the State.

BOX 3 SOME RELEVANT ITALIAN LEGAL STRUCTURE CHANGES (1993-2014)

\begin{tabular}{|c|c|}
\hline 1993 & Decriminalization of the crime of illegal financing of parties and reintroduction of secrecy in investigations. \\
\hline 1994 & $\begin{array}{l}\text { Prohibited preventive arrest for crimes against Public Administration and the Financial System. The population } \\
\text { criticized this decree, which was in force for only one week, enough time to damage the operations underway. }\end{array}$ \\
\hline 1997 & $\begin{array}{l}\text { Altered evidence production rules. Even though the law is more interested in the assurance of rights, the } \\
\text { change nullified much of the evidence used in the lawsuits. This led, in practice, to the prescription of many } \\
\text { crimes. }\end{array}$ \\
\hline 1997 & Reduces the scope of the crimes of "abuse of position." \\
\hline 2001 & Prohibiting of preventive arrest and production of evidence by intercepting telephone communication. \\
\hline 2003 & $\begin{array}{l}\text { Suspension of lawsuits against the Presidents of the Republic, of the Chamber of Deputies, of the Senate, of } \\
\text { the Council of Ministers and the Constitutional Court. Sentence 24/2004, by the Constitutional Court, found this } \\
\text { law unconstitutional. }\end{array}$ \\
\hline 2005 & $\begin{array}{l}\text { Modification of the Italian Penal Code in order to allow house arrest only for the accused and condemned over } \\
70 \text { years of age. Berlusconi was about to turn } 70 \text {. }\end{array}$ \\
\hline 2014 & Publication of delegated law, which decriminalizes crimes of tax evasion. \\
\hline
\end{tabular}

Source: Elaborated by the authors based on Guimarães (2016).

Regarding the effectiveness of public control agencies, the evaluation is not favorable. Sberna and Vannucci (2013, p. 589) perceive the perpetuation of the ineffectiveness of internal and external administrative and judicial controls in Italy. For the authors, "the systemic loopholes in the judicial system made the prosecution of corruption crimes ineffective most of the time." It is necessary to point out that in 1999, a Legislative Decree reformed the internal controls of the government through the restructuring of the mechanisms of control and evaluation of the local public administration (Paglietti, 2010). This reinforces the thesis that overcoming systemic corruption requires action involving all institutions at the same time, as advocated by Rothstein (2007).

On the side of the collective force as a constraint against systemic corruption, as argued by Mungiu-Pippidi, Garcia, and Teodósio (2017) show that, in the 1990s, Italy presented high levels of indices for the indicators associations and civic activism. However, there was no social pressure for change in public governance. The society has one of the highest social welfare rates in the world, such as life expectancy, educational attainment and human well-being. The excellent indexes may explain why there was no strong social pressure for changes in public governance in parallel to Operation Clean Hands. 
Sberna and Vannucci (2013, p. 598) emphasize three aspects about the Clean Hands Operation: a) the politicization of the "anti-corruption issue," with an institutional conflict between the political power and activism of the judges and prosecutors; b) the collapse of the party system; c) corruption affects society as a whole, including the public administration, civil society and the private sector. Box 4 summarizes the case.

BOX 4

THE ITALIAN CASE OF FIGHTING CORRUPTION IN THE '90S

\begin{tabular}{|c|c|}
\hline Transition Time: & About 10 years (1992 -2002). \\
\hline Scope of the Changes: & $\begin{array}{l}\text { It involved the action of a small group from the Italian judiciary in the interface of public } \\
\text { authorities with the private sector elite. There was not a movement of change covering } \\
\text { the country's institutions. }\end{array}$ \\
\hline The trigger: & $\begin{array}{l}\text { Judicial action confronted public and private interface corruption practices that caused } \\
\text { the collapse of the political parties. }\end{array}$ \\
\hline Institutional background: & $\begin{array}{l}\text { Criminal procedure and public prosecution reform in } 1988 \text { establishing the possibility of a } \\
\text { collaborative agreement (patteggiamento). }\end{array}$ \\
\hline Collective force: & $\begin{array}{l}\text { In Italy, corruption seems to be a pervasive phenomenon that affects society as a whole. } \\
\text { During the time of the Clean Hands Operation, civil society did not act against the spread } \\
\text { of corruption, despite the widespread popular support given to judges' actions. }\end{array}$ \\
\hline
\end{tabular}

Source: Elaborated by the authors.

In conclusion, three relevant ideas emerged from the Italian case: a) the insufficiency of the control or judicial system to work as a trigger to provoke an institutional agreement for overcoming systemic corruption; b) the risk of the politicization of the anti-corruption issue causing collapse of politics; and c) popular support given to judges does not mean that civil society is acting against the spread of corruption.

\section{THE BRAZILIAN CASE}

A challenge for the analysis of the Brazilian case is the fact that Operation Car Wash is still in action. However, the paths of the ongoing Operation, which seems to be losing strength, are under public and judiciary debate. There are allegations of excesses by the investigators, especially after the news organization 'The Intercept' published, in June-August 2019, leaked private messages exchanged between prosecutors and judges involved in the operation. The Law on Abuse of Authority (Sept./2019) was approved, the Supreme Court imposed limits on the use of reports of the Financial Intelligence Unit of the Internal Revenue Service, and other administrative bodies in criminal investigations (July/2019) and the Supreme Court has changed the understanding of the time of arrest of legal convicts, now requiring the exhaustion of all possibilities of appeal (Nov./2019). Hence, this analysis is of an ongoing case. 
The analyses of the Swedish and Italian cases allow the consideration of three central elements to analyze the current attempt to overcome systemic corruption in Brazil. They are the trigger, the institutional background, and the collective force. These central elements are used to provide a basis for the understanding of the limits of the effectiveness of public accounting and control systems in the context of systemic corruption. The subsections below analyze the effects of each of the three central elements for the Brazilian case.

\subsection{The Institutional Background}

Brazilian history shows many institutional crises caused by corruption scandals. In the past, the fragility of the accounting and control systems, which are situated at the federal level, was considered the root cause of this problem. This article argues that such a conclusion may no longer hold true, because, in the 1980s and 1990s, Brazil made tremendous progress in these systems (Castro \& Garcia, 2004).

An economic crisis in the early 1980s contributed to the visibility of the "[...] congenital process of corporatist and patrimonialist assault on the State ..." (Gouvêa, 1994, p. 174). It also evidenced the inconsistencies of financial reports, the unreliable character of balance sheets, and the precarious ability to control public spending. As stated by President Sarney, the first President after the redemocratization of Brazil, "it was not possible to calculate public deficit" (Castro \& Garcia, 2004, p. 94). Considering this scenario, many important bureaucrats were convinced that changes were imperative.

This conviction provoked endogenous institutional cooperation in the government and the decision to create adequate accounting and financial control systems. Shortly after the end of the military dictatorship, in 1985, the federal government began to establish reliable accounting and financial management systems (Gouvêa, 1994). In 1986, the Secretary of the National Treasury (STN) was created, centralizing the Accounting, Financial Administration, and Internal Control Systems. One year later, the state put into operation the Integrated System of Financial Administration (SIAFI Sistema Integrado de Administração Financeira). Together with the SIAFI, the government adopted the Conta Unica do Tesouro Nacional (single account of the national treasury), which made accounting a structure that, similar to a bank, held all analytical and original data and started to be a source of information (Castro \& Garcia, 2004).

The 1988 Constitution consolidated the changes that occurred in the accounting and internal control systems. However, it also strengthened the external control of the Public Administration, especially with the role of the Federal Court of Accounts (Tribunal de Contas da União), the Federal Police Department (Departamento da Polícia Federal), Federal Prosecution Office (Ministério Público Federal) and civil society (Avritzer \& Filgueiras, 2011). Despite this strong structure, five years later, two other scandals emerged. In 1992, President Collor was impeached, motivated by corruption. In 1993, there was a major scandal of the National Congress with the revelation of deviation schemes in federal budgets. In 1994, the official explanation for the institutional crisis caused by these scandals was the fragility of internal control.

The solution implemented was the creation of the Federal Secretary for Internal Control (Secretaria Federal de Controle Interno - SFC), subordinated to the Ministry of Finance (MP 480/1994). The SFC and the STN form the Internal Control System of the Federal Executive Branch. They have autonomy and centralized the roles of financial administration, accounting, and control at the federal level. Seven 
years later, the Law 10.180/2001 institutionalized these three roles in separate systems (accounting, financial administration, and control). The first two roles were operated under the responsibility of the STN and the latter under the responsibility of the SFC. In 2003, the Comptroller General (Controladoria-Geral da União - CGU) was created, incorporating the Secretary for Internal Control and expanding its functions to include an ombudsman, combating corruption, and correction. Figure 1 shows how systems work, under the supervision of the external control of the Federal Court of Auditors.

\section{FIGURE 1 THE BRAZILIAN FEDERAL SYSTEMS OF ACCOUNTING AND FINANCIAL CONTROL}

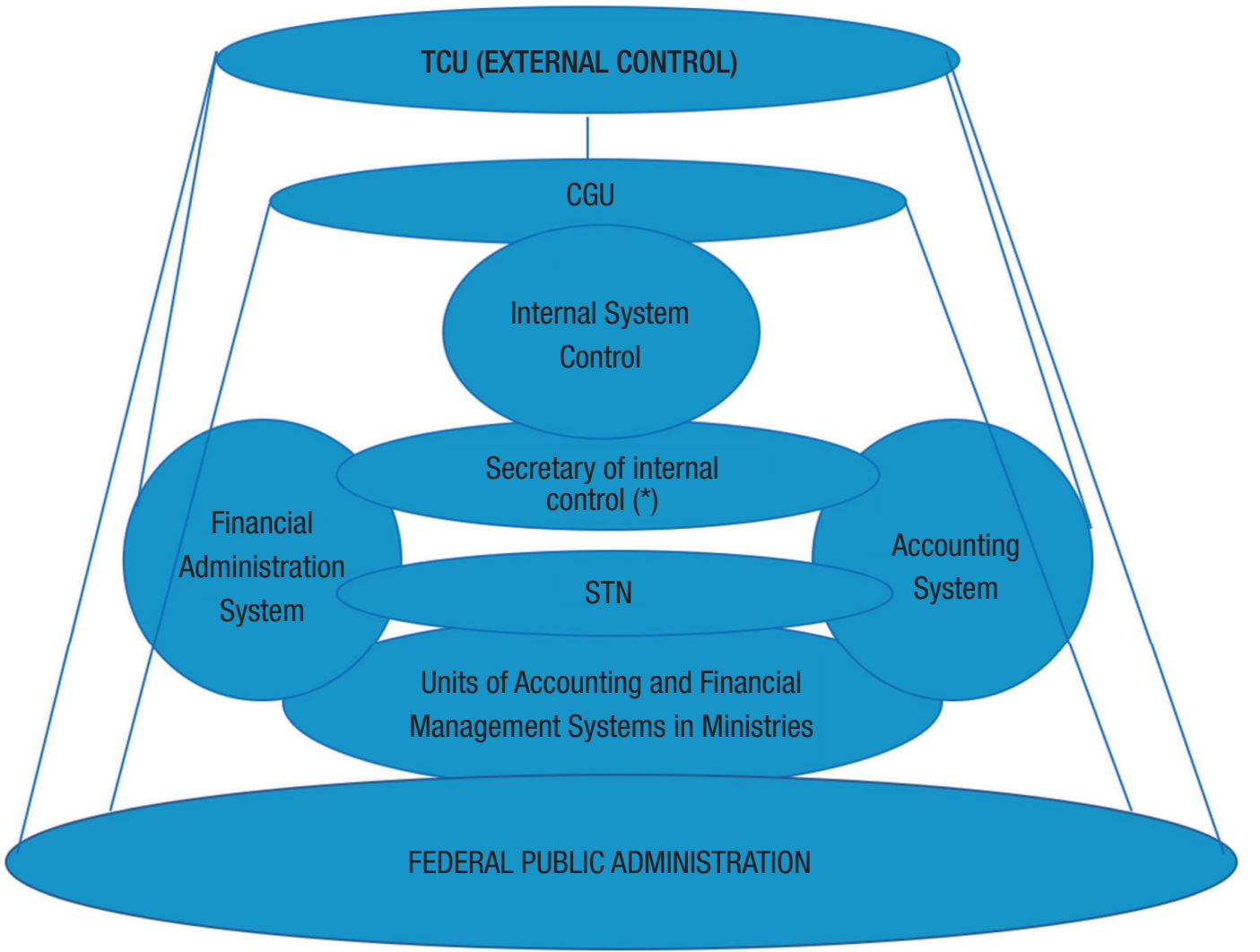

$\left({ }^{*}\left({ }^{*}\right)\right.$ The Office of the Chief of Staff (Casa Civil da Presidência da República), the Federal Attorney General’s Office (Advocacia-Geral da União), the Ministry of Foreign Affairs (Ministério das Relações Exteriores) and the Ministry of Defense (Ministério da Defesa) have their own organ of internal control.

Source: Elaborated by the authors.

At the time this structure was formed, during the 1990s, new laws of control were created in the country, shown in Box 5. They have improved the Brazilian state enforcement. 


\begin{tabular}{|c|c|}
\hline YEAR & NEW LAWS \\
\hline 1990 & Law 8112 - established public tender for the occupation of public office careers. \\
\hline 1992 & $\begin{array}{l}\text { Law } 8429 \text { - criminalized acts against public heritage and provided penalties for public officials in cases of } \\
\text { illicit enrichment. }\end{array}$ \\
\hline 1993 & $\begin{array}{l}\text { Law } 8666 \text { - established rules for public procurement, criminalizing the deliberate actions to thwart the } \\
\text { achievement of tenders and public procurement. }\end{array}$ \\
\hline 2000 & $\begin{array}{l}\text { Supplementary Law } 101 \text { - established crimes of fiscal responsibility (to spend public money beyond the limits } \\
\text { of the law) and defined the obligation of transparency in implementing the budgets and social participation } \\
\text { mechanisms. }\end{array}$ \\
\hline 2001 & $\begin{array}{l}\text { Law } 10180 \text { - regulated the administrative systems of the federal government (planning area, budget, financial } \\
\text { administration and accounting, and internal control). }\end{array}$ \\
\hline 2009 & $\begin{array}{l}\text { Supplementary Law } 131 \text { - determined the availability, in real-time and on the Internet, of detailed information } \\
\text { on the budgetary and financial management of the Union, the States, the Federal District, and the } \\
\text { Municipalities. }\end{array}$ \\
\hline 2010 & $\begin{array}{l}\text { Supplementary Law } 135 \text { - known as "Lei da Ficha Limpa," limited the participation in elections in case of } \\
\text { various types of crime, like crimes against the Government, crimes against the environment etc. }\end{array}$ \\
\hline 2011 & Law 12. 527 - law of access to public information. \\
\hline 2013 & Law 12.846 - anti-corruption law. \\
\hline 2013 & Law 12.850 - defined, among other things, the collaboration agreement. \\
\hline
\end{tabular}

Source: Elaborated by the authors.

It is possible to conclude that Brazil constituted strong systems of bureaucratic and judicial control in the last 30 years. The expectation was that the existence of specialized agencies to supervise and punish possible acts of corruption committed by public agents could help Brazil to overcome the problem of corruption. Unfortunately, this did not happen, as the next subsection will show.

\subsection{The Trigger: Operation Car Wash}

The Operation began on March 17, 2014, when the Federal Justice authorized the Federal Police to carry out the first phase of the operation, arresting Youssef, a black market dollar dealer, and subpoenaing Paulo Roberto, former manager of Petrobrás, ${ }^{1}$ to testify. Like the Italian Operation, the offenders accepted to turn state's evidence, and investigative techniques against money laundering and criminal organizations played an important role in the process of uncovering corrupt practices in the interface between political parties and the private sector. It was possible to prove the formation

\footnotetext{
${ }^{1}$ Petrobras is a Brazilian oil and gas company established in 1953 as a state-owned enterprise. Since 1977 its stocks are listed on the Brazilian Stock Exchange, although it is still a subsidiary from the Federal Government. For more than three decades Petrobras was the biggest company traded in the Brazilian capital market.
} 
of cartels in several economic sectors, mostly involving the country's largest contractors, with severe financial losses for the contracting state-owned companies.

Due to the complexity of the operation, an investigative task force of Prosecutors of the Republic was formed for the investigation work in the first instance of the Federal Court of Paraná. The task force, all the time, has been working together with the Federal Police and the Federal Revenue Secretariat (in Brazil called Secretaria da Receita Federal). These bodies were occasionally joined by members of the Federal Comptroller, the Administrative Council for Economic Defense, and members of Petrobrás.

During the investigation, collaborative agreements, particularly those made with the staff of the companies Odebrecht ${ }^{2}$ and $\mathrm{JBS}^{3}$, have proved that the behaviors unveiled in the Operation were not a deviating fact, but rather the standard behavior in the interface between the public and the private sectors. After a little more than five years, the Operation had had an impact on the economic elite due to the arrest of important business people.

The legitimacy of politicians and that of the state was challenged. In the specific case of the Executive Power, one of the outcomes of the losses on legitimacy was the impeachment of former president Dilma Rousseff, which was made possible, to a great extent, due to the loss of legitimacy of the political party to which she belonged, the Workers' Party (PT). Other outcomes were the imprisonment of former president Lula and the former president of the Chamber of Deputies, Eduardo Cunha. Former president Temer is now under investigation, after being released from preventive detention.

According to the Federal Prosecution Office (Ministério Público Federal), on July 5, 2019, the numbers of Operation Car Wash were: 2,476 inquiries, 754 requests of international collaboration, 155 preventive arrests, 183 collaborative agreements, 11 leniency agreements, and 1 conduct adjustment agreement. There are still criminal charges against 421 people, 159 already sentenced.

\subsection{The Brazilian Collective Action}

Avritzer (2016, p. 6) affirms that Brazil "[...] by any significant criterion proposed by theories that measure the state of the art of democracy, the country is in a good position". Nonetheless, Brazil has never succeeded in building a democracy that is genuinely focused on the common good. It has remained an electoral democracy, without a real sense of universalism and the common good. Brazilian social construction has always presented a high level of social inequality and low levels of trust and social capital. The economic, political, and bureaucratic elites have always received high income, better public services than the average Brazilian, and, to a certain extent, have put themselves above the law.

In general, they build ties with the Government and the Judiciary in order to be benefited by the laws. Carvalho (2008:215) affirms that, in Brazil, "[t]here are first-class citizens, the privileged people, the 'doutores' who are above the law and always manage to defend their own interest through the power of money and social prestige. The 'doutores' are invariably white, rich, well-dressed, with

\footnotetext{
${ }^{2}$ Odebrecht SA is a private business conglomerate of Brazilian origin (1944) that operates in various parts of the world in the areas of construction and engineering, chemistry and petrochemicals, energy, among others. In 2001, Odebrecht became the largest petrochemical group in South America. In June 2019, it filed for judicial recovery.

${ }^{3}$ JBS S.A. is a Brazilian company founded in 1953. It is one of the largest food industries in the world. Since 2007, its stocks are listed on the Brazilian Stock Exchange.

${ }^{4}$ Retrieved from http://www.mpf.mp.br/grandes-casos/caso-lava-jato/atuacao-na-1a-instancia/parana/resultado
} 
university education". So, considering Tocqueville's theory, it is not yet possible to affirm that there is, in practice, popular sovereignty in Brazil. There is no indication of significant changes in the ability of Brazilian society to effectively interfere with the institutions in a way that solves civic or public interest problems. Table 1 demonstrates the period after the re-democratization of Brazil and shows some social indicators that may help the analysis of the idea of collective force in Brazilian society.

\section{TABLE 1 COLLECTIVE FORCE - BRAZIL}

\begin{tabular}{ccccc} 
Year & Civic Activism & $\begin{array}{c}\text { Intergroup } \\
\text { Cohesion }\end{array}$ & $\begin{array}{c}\text { Clubs and } \\
\text { Associations }\end{array}$ & $\begin{array}{c}\text { Interpersonal Safety } \\
\text { and Trust }\end{array}$ \\
\hline 1990 & 0.587 & 0.643 & 0.440 & 0.477 \\
2000 & 0.530 & 0.497 & 0.502 & 0.349 \\
2010 & 0.524 & 0.703 & 0.492 & 0.286 \\
\hline
\end{tabular}

Source: International Social Development Indexes (ISDI, in June 2013).

There was a particularly significant decline in the indicator "Interpersonal_Safety_and_Trust." This indicator reduced from 0,477 in 1990 to 0,286 , in 2010. The other indicators remained relatively constant in that same period. Despite no recent data of the ISDI, a survey on interpersonal trust made by $\mathrm{IBOPE}^{5}$ in 2014 , at the request of the National Confederation of Industry, confirmed this declining trend. According to the survey, only $6 \%$ of the population perceived itself as having much confidence in people in general. In contrast, $31 \%$ indicated that they had some confidence, and the majority did not show any confidence.

On the other hand, it is important to highlight that activism and the association trend of civil society have not shown a significant decline since 1990 . This force of civil society can be seen in the social movements that took place in the country in 2013, which preceded the approval of the anticorruption laws and the collaboration agreement that allowed the emergence of Operation Car Wash. The question, however, is what kind of changes can this force produce without interpersonal trust and a sense of collectivity?

\subsection{Preliminary inferences about the Brazilian case}

The Brazilian case can be summarized, in a very preliminary way, as shown in Box 6. In terms of the trigger and scope of the attempt to change, the Brazilian case bears a resemblance to the Italian case. Concerning the institutional background, there is a similarity in terms of changes in investigative processes (a collaborative agreement, for example). However, Brazil has not gone through law changes to protect offenders and make it difficult to punish deviations, as it happened in Italy. The recent Supreme Court's understanding that offenders convicted in the court of appeal cannot be arrested if

${ }^{5}$ Brazilian Institute of Public Opinion and Statistics. 
there is still legal instances to appeal represents not a change, but an interpretation of a very complex point of the Federal Constitution.

Unlike Sweden and Italy, at the time of their process, regarding the collective force, the condition of Brazilian civil society to defend public interests is much more fragile. The society presents a low level of interpersonal trust and deep social inequality.

BOX 6

SUMMARY OF THE BRAZILIAN CASE

\begin{tabular}{|c|c|}
\hline Process time & About 5 years (since 2014). Operation Car Wash is still underway. \\
\hline Scope of the attempt to change & $\begin{array}{l}\text { It involves the action of groups from the judiciary and institutional control in the interface } \\
\text { of public authorities with the private sector elite. However, this movement does not } \\
\text { cover institutions in general, even if subject to strong pressure from civil society fighting } \\
\text { corruption. }\end{array}$ \\
\hline The trigger: & $\begin{array}{l}\text { Strong legal action confronting corrupt practices in the public/private interface, while the } \\
\text { country is experiencing severe economic and political crises. }\end{array}$ \\
\hline Institutional background: & $\begin{array}{l}\text { Since the 1980s, the structures and mechanisms of accounting and control systems at } \\
\text { the federal level have strengthened. }\end{array}$ \\
\hline Collective force: & $\begin{array}{l}\text { The civil society has a high level of activism and association. However, people do not have } \\
\text { interpersonal trust and a sense of collectivity. }\end{array}$ \\
\hline
\end{tabular}

Source: Elaborated by the authors.

In addition to the crisis of legitimacy of the State, Brazil has faced a deep economic crisis since 2014. The Brazilian society is severely impacted, and it has difficulty in advocating for principles of social cohesion. In the last federal elections of 2018, a strong social movement led to the rejection of traditional and more consolidated political parties.

The current institutional setting is complex and challenging. However, there are still no signs that these crises are enough to be understood as a new trigger able to provoke an endogenous institutional solution, as it occurred in Sweden in the nineteenth century, despite the fragility of civil society. Nevertheless, this possibility cannot be ruled out, especially if the political, institutional, and economic problems are further aggravated. In this context, Sweden's lesson is that a significant part of society, including part of the elites, is aware that everyone can lose and they can decide to work together to change the rules of the dominant social game.

\section{FINAL CONSIDERATIONS}

The literature reviewed indicates that corruption is a matter of contemporary relevance. This is particularly true for countries characterized by systemic corruption - which are the majority in the world. In these countries, there are clear limitations in stabilizing the foundations of the rule of law, such as (a) there is no effective separation between private political gains/economic elites and public 
resources; (b) there is no impersonality in the relations between the public and the private sphere; and (c) the common good stated by positive law is articulated by the economic interest in collusion with politicians, thus trapping the legal structures.

Economic theories, primarily through the principal-agent theory, suggest mechanisms to control public bureaucracy, even in the absence of the "incorruptible principal." Examples of such suggestions are the establishment of institutions and horizontal control agencies. However, the impact of such institutions in states that face systematic corruption is very different from the one in developed countries. In light of the limitations of the principal-agent theory, collective action can complement some possibilities to overcome systemic corruption. Starting from the cases of Sweden, Italy, and Brazil, some points merit reflection in order to overcome the problem of systemic corruption.

The existence of an external phenomenon is necessary to break the perverse balance of systemic corruption. Sweden sought a new equilibrium motivated by war, which demonstrated that the very continuity of the Swedish state could be at risk. Italy and Brazil did not experience an external phenomenon. The fight of the judiciary against certain types of corruption, such as bribes, cannot be characterized as an external phenomenon. The particularity of the Brazilian crisis, however, can be considered an external phenomenon. The crisis in the country combines: (i) a crisis of legitimacy of the political classes with Operation Car Wash (ii) a serious economic crisis; and (iii) a brutal social inequality. This combination is a threat to the democratic order and stability of institutions. It is precisely this threat that may be considered an external phenomenon.

Normative constraints, independent Judiciary, and adequate control systems based on principalagent theory are necessary for encouraging public agents to align themselves with official standards. Sweden had, as a background to its the process of overcoming systematic corruption, a reform of the Judiciary. It instituted new rules of the game for the functioning of the State, as well as mechanisms of control to interface with private interests. While Italy and Brazil each have a control system, its effectiveness in the context of systematic corruption is limited. Their respective control systems were established before the crisis analyzed, and they were absorbed by the rules of the game that were in force.

The change must be endogenous. In Sweden, the comprehensive pact for changing the rules of the game involved the political and bureaucratic fields and involved all areas and all institutions. In Italy, a portion of the Judiciary conducted the prosecution of a specific type of corruption (bribe), which was typical of the relationship between political parties and the market. In this context, Italian political parties and the market protected each other and found a way to overcome the crisis, while, at the same time, not conducting a profound change in the rules of the game. Systematic corruption was thus not overcome. Brazil is now facing a type of confrontation of corruption that appears to be like that of Italy.

Collective force is also a structural condition relevant to overcoming systemic corruption. In Sweden, civil society had a strong movement to build a liberal, efficient, and equalitarian democracy. In Italy, civil society had a high level of political activism and social trust. However, there was no pressure for change in public governance, as this society has one of the highest social welfare rates in the world, such as life expectancy, educational attainment, and human well-being. The social structure of Brazil is different from that of Italy. Since the 1980s, in the reconstruction of democracy, Brazilian society has not yet been able to advance social indexes of well-being. 
Considering that Operation Car Wash is still underway, the possible contribution of this article is to alert against sectarian perspectives of solutions for the problem of corruption in Brazil. A joint effort from leaders from all sectors for a possible pact to change the rules of the corruption game that is in force can be a strategy for change. It is not possible to divide agents into corrupt and non-corrupt. Instead, it is essential to perceive systemic corruption as a problem for everyone.

A new research agenda about public finance, accountability, and corruption control could be improved through the comparative analysis between countries, as done in this article. Some relevant issues related to the political culture of the countries and the trajectory of public policies considering the institutions can bring new insights for these academic issues that are relevant to the society and the policymakers. To advance points that are not focused on in this research such as the role of the private corporations adopting (or not) self-regulation about corruption, the kind of activism against the corruption created by NGOs, and the population's perception about the ethical crimes on public finance, are relevant issues for the new research in this field. 


\section{REFERENCES}

Avritzer, L. (2016). Os impasses da democracia no Brasil. Rio de Janeiro, RJ: Civilização Brasileira.

Avritser, L \& Filgueiras, F. B. (2011). Corrupção e controles democráticos no Brasil. (Textos para Discussão CEPAL-IPEA, 32). Brasília, DF: CEPAL. Escritório no Brasil/IPEA,

Bourdieu, P. (1983). Esboço de uma teoria prática. In R. Ortiz (Org.), Pierre Bourdieu: Sociologia (cap. 2, pp. 46 - 81). São Paulo, SP: Ática, 1983.

Bourdieu, P. (1996). Razões práticas: sobre a Teoria da Ação. São Paulo, SP: Papirus.

Bourdieu, P. (2014). Sobre o Estado. São Paulo, SP: Companhia das Letras.

Carvalho, J. M. (2008). Cidadania no Brasil: um longo caminho. Rio de Janeiro, RJ: ed. Civilização Brasileira.

Castro, D. P. \& Garcia, L. M. (2004). Contabilidade Pública no Governo Federal. São Paulo, SP: Ed. Atlas.

Cunha, E. S. M. \& Araújo, C. E. L. (2018). Process Tracing nas Ciências Sociais: fundamentos e aplicabilidade. Brasília, DF: Enap.

Ferro, R. J. (2015). Vamos lá falar: um estudo psicopolítico da consciência política, a partir das percepções do fenômeno da corrupção em Moçambique. (Master Thesis). Universidade de São Paulo, São Paulo, SP, Brazil.

Filgueiras, F. B. (2007). Teoria Política da Corrupção. Defense in congress. Juiz de Fora, MG: UFJF. Retrieved from http://www.ecsbdefesa.com.br/fts/ TPC.pdf

Filgueiras, F. B. (2009). A tolerância à corrupção no Brasil: uma antinomia entre normas morais e prática social. Opinião Pública, 15(2), 386-421.

Garcia, L. M. (2011). Análise do Controle Interno no Poder Executivo Federal Brasileiro sob a Perspectiva de Pierre Bourdieu: A história social como possibilidade de compreensão da produção e reprodução de práticas dos agentes (Doctoral Dissertation). Universidade Federal de Minas Gerais, Belo Horizonte, MG, Brazil.

Garcia, L. M. \& Teodósio, A. S. S (2017). Approaching systemic corruption as an issue of collective action: a comparative analysis of the cases of Brazil, Sweden and Italy. In Defense in 2017EGPA Annual Conference, Milan, Italy.
Gouvêa, G. P. (1994). Burocracia e Elites Burocráticas no Brasil. São Paulo, SP: Ed. Paulicéia.

Guimarães, P. (2016). Os escandinavos. São Paulo, SP: Contexto.

Guimarães, R. R. C. (2016). Déjà vu: diálogos possíveis entre a Operação "Mãos Limpas" italiana e a realidade Brasileira. Revista Jurídica do Ministério Público do Estado do Paraná, 3, 189-233. Retrieved from http://www.mpf.mp.br/regiao3/ sala-de imprensa/docs/2016/artigo-rodrigochemimmaoslimpaserealidadebrasileira.pdf

Jensen M. C. \& Meckling, W. H. (1976). Theory of the firm: Managerial behavior, agency cost, and ownership structure. Journal of Financial Economics, 3(4), 305-360. Retrieved from https://www.sciencedirect.com/science/article/ pii/0304405X7690026X

Krueger, A. O. (1974). The political economy of rent-seeking society. The American Economic Review, 64(3), 291-303. Retrieved from http://www.jstor.org/ stable/1808883

Mungiu-Pippidi, A. (2013a). Controlling Corruption Through Collective Action. Journal of Democracy, 24(1), 102-113. Retrieved from https://www. journalofdemocracy.org/articles/page/73

Mungiu-Pippidi, A. (2013b). Becoming Denmark: Historical Designs to Corruption Control. Social Research: An International Quarterly, 80, 12591286. Retrieved from https://www.researchgate.net/ publication/265812682.

Mungiu-Pippidi, A. (2015). The Quest for Good Governance How Societies Develop Control of Corruption. London, UK: Cambridge University, 2015.

Moro, S. F. (2004). Considerações sobre a operação "Mani Pulite". Revista do CEJ, 26, 56-62. Retrieved from https://www.conjur.com.br/dl/artigo-moromani-pulite.pdf

Ostrom, E. (1990). The Evolution of Institutions for Collective Action: Political Economoy of Institutions and Decisions. London: Cambridge University Press.

Persson, A., Rothstein, B. \& Teorell, J. (2013). Why Anticorruption Reforms Fail-Systemic Corruption as a Collective Action Problem. An International Journal of Policy, Administration, and Institutions, 26(3). Retrieved from https://doi.org/10.1111/ j.1468-0491.2012.01604.x 
Paglietti, P. (2010). Internal Controls and Auditing in Italian Local Governments. In Annals of the 10th Global Conference on Business \& Economics, Roma, Italy. Retrieved from http://www.gcbe. us/10th_GCBE/data/confcd.htm

Putman, R. D. (2006). Comunidade e democracia: a experiência da Itália moderna. Rio de Janeiro, RJ: FGV.

Rose-Ackerman, S. (1978). Corruption: a study in political economy. New York, NY: Academic Press, 1978.

Rose-Ackerman, S. (2002). A economia política da corrupção. In K. A Elliott (Org.), A Corrupção e a Economia Global (pp. 59-105). Brasília, DF: UNB.

Rothstein, B. (2007, May). Anti-Corruption - A Big Bang Theory. The Quality of Government QoG (Working Paper Series 2007:3). QoG the Quality of Government Institute, Gothenburg, Sweden. Retrieved from http://www.pol.gu.se/ digitalAssets/1350/1350652_2007_3_rothstein.pdf

Rothstein,B \& Varraich, A. (2017). Making Sense of Corruption. London: Cambridge University Press.

Sberna, S \& Vannucci, A. (2013). "It's the politics, stupid!". The politicization of anti-corruption in Italy. Crime Law Soc. Change, 60, 565-593. Retreived from http://weblaw.haifa.ac.il/en/ JudgesAcademy/workshop3/Documents/A/D/ Its\%20the\%20Politics.pdf

Stefes, C. H. (2007). Measuring, Conceptualizing, and Fighting Systemic Corruption: Evidence from Post-
Soviet Countries. Perspectives on Global Issues, 2(1), 1-16. Retrieved from http://citeseerx.ist.psu.edu/viewdoc/ download?doi=10.1.1.499.8875\&rep=rep1\&type $=$ pdf

Teorell, J. \& Rothstein, B. (2012, December). Getting to Sweden: Malfeasance and Bureaucratic Reforms, 1720-1850. (Working Paper Series 2012:18). QoG the Quality of Government Institute, Gothenburg, Sweden. Retrieved from https://qog.pol.gu.se/ digitalAssets/1418/1418045_2012_18_teorell_ rothstein.pdf

Tocqueville, A. (2005). A Democracia na América. São Paulo, SP: Martins Fontes.

Vannucci, A. (2009). The Controversial Legacy of "Mani Pulite": A Critical Analysis of Italian Corruption and Anti-Corruption Policies. Bulletin of Italian Politics. University of Pisa, 1(2), 233264. Retrieved from http://www.gla.ac.uk/media/ media_140182_en.pdf

Vannucci, A. (2016). The "Clean Hands" (Mani Pulite) Inquiry on Corruption and its Effects on the Italian Political System. Em Debate: Periódico de Opinião Pública e Conjuntura Política, 8(2), 62-68. Retrieved from http://bibliotecadigital.tse.jus.br/ xmlui/handle/bdtse/3287

Vasconcellos, V. G. (2015). Barganha no Processo Penal Italiano: Análise Crítica do Patteggiamento e das Alternativas Procedimentais na Justiça Criminal. Revista Eletrônica de Direito Processual - REDP, 15(1), 435-453. Retrieved from www.redp.com.br

\section{Leice Maria Garcia}

http://orcid.org/ 0000-0001-9456-1009.

Postdoctoral student in Administration by Pontifical Catholic University of Minas Gerais (Puc Minas); PhD in Management from Center for Research and Graduate Studies in Business Administration at Federal University of Minas Gerais (CEPEAD/UFMG); Finance and Control Auditor at the Comptroller General of the Union/ Federal Government of Brazil. E-mail: leice.garcia@gmail.com

\section{Armindo dos Santos de Sousa Teodósio}

https://orcid.org/0000-0002-7835-5851

$\mathrm{PhD}$ in Management from Fundação Getulio Vargas's São Paulo School of Business Administration (FGV EAESP); Associate Professor at Pontifical Catholic University of Minas Gerais (PUC Minas).

E-mail: armindo.teodosio@gmail.com 